Јеленка Пандуревић

Катедра за србистику

Филолошки факултет

Универзитета у Бањој Луци

jelenka.pandurevic@flf.unibl.org

https://doi.org/10.18485/ai_san_o_gradu.2019.ch1

821.163.4(497.6)-34:398

\title{
НАРОДНА ПРЕДАҢА О ГРАДОВИМА: УСМЕНА ИСТОРИЈА ИЛИ КУЛТУРНО ПАМЋЕЊЕ
}

у приступу народним предањима забиљеженим у Босни и Херцеговини феномени усмене традиције и културног памћења представљају се кроз креативни усменопоетски дијалог између фикције, историје и мита. Тврђаве, насеља и грађевине предмет су прича о владарима и власницима, грађењу и задужбинарству, рушењу и освајању, али и о вјеровањима која се везују за остатке рушевина. Као специфичан амалгам митског мишљења и историјског памћења, у овом раду издвајају се комплекси предања о женама градитељицама, и нуди преглед досадашњих проучавања и актуелних тумачења.

Кључне ријечи: народна предања, тврђаве и градови, градитељице и владарке, усмена историја, културно памћење.

\section{1. Увод}

Предања су причања која се, за разлику од осталих прозних врста усменопоетског система, заснивају на вјеровању у реалност онога што се казује (потврђену „материјалним“ доказима), као и на доживљају застрашујућег, необичног и изванредног. Локално предање 
је сабирна тачка у којој се често сустижу историјске и митолошке реминисценције и преокупације неког културног ареала. Тако фантастика демонолошких предања почива на имагинарном и наративном суочавању са оностраним, док су за изузетност и несвакидашњост историјских предања заслужне изузетне личности, „уз фасцинацију прошлошћу, као нечим што је постало туђе“" (Bošković Stulli 1975: 130).

Предмет овог рада су локална културноисторијска предања која су, за разлику од демонолошких, па и од етиолошких и есхатолошких, много мање подложна субјективним варијацијама у исказу и вредновању. У њиховом обликовању учествују различити токови традиције, а ауторитет колектива или предака одржава њихову релативну стабилност. Док митолошко или демонолошко предање остају у домену вјеровања у аутентичност личног искуства, историјско предање се позива на категорију „знања“, културног памћења заједнице које се ослања на материјалне остатке прошлости (грађевине, споменике, локалитете, рушевине и сл.) и механизам глорификације историјских личности. У позадини многих очигледно псеудоисторијских предања назире се реалност друштвених релација и начина живота и стога ce, упркос свим анахроним структурама и непрецизностима у погледу локализације и актера, овај усмени наратив потврђује као свједочанство енормне способности памћења у усменој култури (в. Röhrich 1966: 47-55). Одавно уочен парадокс у вези са историјским и културноисторијским предањима могао би се сажети у констатацију да, упркос свим измишљеним детаљима и историографским нетачностима, предање у својој суштини чува „истиниту историју“ епохе.

Предања о градовима, која су у најужем смислу предмет овог рада, свједоче о историји културе и цивилизације подржавајући широко распрострањене нара- 
тивне типове, при чему се локалне варијанте уграђују у структуре националног памћења конкретизацијом личности, догађаја и историјских конфронтација. Корпус је издвојен из једине цјеловите збирке културноисторијских предања записаних у Босни и Херцеговини (Палавестра 2003) ${ }^{1}$, и допуњаван разнородним записима на српском језику по принципу тематско-мотивских типолошких аналогија, без обзира на жанровску припадност, како би се потврдиле хипотезе о наслојавању митопоетских образаца у процесу усменопоетског осмишљавања националне историје. Модел на коме ће се овај процес конкретизовати и потврђивати обухвата реалне историјске личности и митолошке наративе, односно метафоре као што су мит о амазонкама, златном добу и изгону из раја, подизање града, ткање, утамничење, заптивање воде. Избор критеријума (у овом случају наратива о градовима који се обликују посредством женских ликова) долази као посљедица уочених изоморфних структура (Палавестра 2003: 3839; 306; уп. Пандуревић 2008: 96) у усменопоетској тематизацији и стилизацији феномена град. Предањима о градозидању доминира женско начело, при чему су конкретизације и семантизације остварене у широком распону између митског и историјског пола у систему стварања и преношења усменог пјесништва. Крајности овог сижејног модела обиљежавају с једне стране демијуршки ликови бабе и Црне краљице, чијом дјелатношћу се обликује рељеф, које знају тајне вода и космичких ритмова, као и њиховим митолошким профилима блиске безимене ткаље и похотљиве амазонке, а са друге стране њихова наличја, која у одабраном

1 Сва предања у овом раду, без обзира на природу записа, наводе се према збирци Влајка Палавестре, уз навођење примарних извора, како су тамо наведени. 
корпусу носе имена српске деспотице Јерине, босанске краљице Катарине и аустријске царице Марије Терезије $\mathrm{e}^{2}$. Циљ овога рада је да се додатном аргументацијом потврди већ исказана хипотеза (Пандуревић 2008: 92; уп. Пешикан Љуштановић 2007: 99-133) да парадокс доминантне жене, владарке и градитељице, у патријархалном коду традиционалне културе народно предање разрјешава додјељујући актерима статус бића надмоћног „по врсти“. Уочено је да градови и утврђења, као свједочанства историјских епоха, функционишу и у семантичком простору митолошких слика и метафора које су рефлекс космогонијских ритмова и евокација свете свадбе. У овом избору и тумачењу, капије, зидине, тунели и тамнице постају позорнице на којима се архетипска амбивалентност женског начела преиспитује и потврђује кроз структуре фундаменталних опозиција свој-туђи и мушко-женско, односно њихових просторних и временских координата.

\section{2. Грађа: избор и извори}

2.1. Прије, каже, у старо вриме да Сава није била нуде, већ баба пробраздила плугом, и ето, постала Сава, и ето, видиш, ринула, ринула и видиш колка је постала. ФАЗМ XIV-Г, 5568.

2.2. Више села Конгоре (Дувањско поље - ВП) има градина. Причају да у градини има златна кућа и у кући златна цура и златан стан на коме она тка. Некад се, кажу, чује како тка. На градини има зидина за које се прича да су остаци кућа које су тамо подигли људи који

2 Изван граница одабраног корпуса на готово истовјетан начин функционишу и неке друге „владарке“, као нпр. илирска краљица Теута. 
су из поља побјегли горе испред потопа, кад је потоп био. ФАЗМ XVI-Г 6199.

2.3. Била ника Црна краљица римска, па овди у Прилуци имала град, гори на брду. Зове се Градац. Протирали је Турци, она је бижала, потковала коње наопако и тако утекла. Прича се да је имала златну квочку и златне пилиће и златан стан. ФАЗМ, IX-Г, 4902.

2.4. Турци опколе град, али му тврђи не могну за дуго времена ништа учинити. Пошто су се на све начине узалуд мучили, рећи ће им једна баба: „Затворите коња пастуха, па му не дајте за три дана воде, а онда га пуштајте и добро гледајте гдје ће закопати ногом! Ондје копајте па ћете наћи воду што иде у град, па им пресијеците! Кад воду пресијечете, град ће се предати“. Тако они и ураде. Кад у граду понестане воде, нареди краљица, те коње поткују наопако, натовари благо и нотњо побјегне. Приповиједају да је при тој прилици убила краљица са „Кози града“ из топа турског заповједника спрам себе у остружници, 4 сата далеко. Када заповједника свукоше да га окупају, видјеше да је женско“. Грђић-Бјелокосић 1892, 91.

2.5. Ударили Турци на град изнад села Сјеверина, ударали узаман, нису га могли освојити никако. Опсједајући тако град нађу међу стијенама, куда тече вода Сућеска, неку бабу и обећају јој велико благо само да им каже начин како ће истјерати Јерињу из града. Баба се на паре полакоми и вели им овако: „Нађите црвена коња ждријепца од седам година и седам мјесеци, дајте му јечам кроз три дана, а не дајте му воде пити. И онда пустите коња према Јеловику, а ђе коњ закопа ногом, ту је вода и ту су чункови, што воду воде у град, одвратите воду, и Јериња ће тако сама изаћи“. Тако је и било. Турска војска прекинула воду, а Јерињи дотужила жеђ, из дана у дан све то више. И Јериња морала напустити 
град, провукла се на тајна врата и окренула према шуми Јаворју. А понијела са собом и благо на мазги. Од брза хода и тешка блага мазга угинула у путу под товаром, таман код Рохоч воде, у стијенама, и тако се то мјесто прозвало отуд именом Мазгина стијена. Јериња благо закопала у близини тога врела, четерес аршина од врела на неку страну, не зна се на коју, и отишла својим путем. Данданас не знају се ни врата града, зазидала их Јериња, а била су од сунца. Тако ни турска војска није могла наћи улаз па није никад ни ушла у град, а нити је ико други ногом крочио унутар до данас. Bejtić 1958: 4-8.

2.6. Кад се турска војска поприкучила граду, онамо с горње стране, владарица ђевојка је војску све оком разабирала па је једном рекла: „Ено онди су највише турске змије!“, и отада се оно мјесто, ено га изнад гробља, по томе прозвало Змијача. Кад је на крају крајева владарица видјела, да се град мора предати, отворила капију једном виђеном момку јунаку, а све у таквој намјери, да је онај јунак узме себи за љубу, да јој спаси живот. А момак јунак, како закорачио у град, тако и посјекао капиџију на капији и упустио војску у град. Настала трка и метеж, ни момак јунак ни војска нису се ни обазирали на владарицу. А у том метежу владарица ђевојка, кад је видјела да јој онај момак јунак ни мукајет није, искраде се из града, изађе сама самцата, нико је ни додирнуо није. Узела само торбицу са дукатима са златна стана, просипала дукате путем, да се војска забави дукатима и да је не стигне, и окренула путем уз Лим. Кад је била, на прилику, једно хиљаду корачаја далеко од града, нешто се обазре, кад ли за њом у трку Циганин, што је калајисао казане у турској војсци, са голом сабљом у руци. Владарица је ту клонула и закукала: „Куку мени, љуто ти ми дође!“ И Циганин јој је ту живот докрајчио. Покопана је на оном истом мјесту ис- 
под пута, гроб јој се и данас зна, велик је, има сантрач, али нема гробних каменова. По оном кукању мјесто, ђе је владарица пала, зове се и данас Кукавац, а село више тог мјеста прозвало се Љутова. Bejtić 1958: 4-8.

2.7. Град је припадао некој краљици Катарини. У град је била чунковима доведена вода са планине Чемернице. На истој планини краљица је имала свој мал. Кад га помузу, онда чобани одбију воду и кроз чункове пусте млеко у град. Оне године кад ће изгубити град, имала је краљица на Чемерници и посејан лук. Једног дана јој чобан јави на свиралу: „Нико у Бостану омарић, оде из Босне краљић!“ Кад краљица оде на планину и виде то, рече: „Мени више нема стања“. За неко време навале Турци. Филиповић 1924, 103.

2.8. Јериња је била, ето тамо, у том граду вратарском. А други јој је град био према Старом Броду, па јој је тамница била више Вишеграда. Не знам каква је држава њу ишћерала, само се прича да је потковала коње наопако, и, кажу, побјегла. Наше комшије Срби зову је Проклета Јерина ФАЗМ XXV-Г 13860.

2.9. У околини града Вратара, код Жепе (Рогатица) живјеле су три сестре - владарке: једна је живјела на Старом Броду на Дрини, друга на Клотијевцу на Дрини, а трећа на Вратару. Хватале су и злостављале људе. На Вратару је становала Јерина, па је у граду имала златан стан и златно је платно ткала. Палавестра 1964.

2.10.„Град“ у Бјелају је нека баба Јерина градила, жена угарског краља. То је било прије турског вакта. На граду има тамница, уокруг озидана, али воде на граду нема. ФАЗМ, теренска свеска, ВП.

2.11. Мој стриц ми је причао да је овај град Тржац некад грчки град био. Да га је зидала једнога краља ћерка, по имену Трга. Зато је зазван - град Тржац. То су биле три сестре: Бихаћ је градила Бика, Сока Соколац, 
а Трга Тржац. Зато су зазвани ти градови по тим именима ФАЗМ, IX-Г, 4648

2.12. Више Старог брода на Дрини има једно мјесто које се зове Град. Ту, близу села Хртара има једна пећина и тамо је стајала краљица Јериња. Она је имала своју војску. А био је неки Химзи-бег, па и он имо војску. Кад би јој затребај мушко, она узми по ноћи војника и ноћи с њиме, па га ујутро убиј да не казује. Кад се једном помокрио тај турски војник, она опазила ону пјену, па јавила Химзи-бегу да ноћу пошаље војника, даће му лубеницу пара. ФАЗМ XXII-Г, 13705.

2.13. Прича се да је била Црна краљица, Терези Марија. Зовне војника, „оправи“ с њим, и убије га послије. ФАЗМ, теренска свеска, записао ВП у Босанском Петровцу 1970.

2.14. Има једна прича како је сестра Јеринина подигла свој град насупрот Зворнику; Јерина завидна позове сестру у госте, умоти је отровом, те узе тај сестрин град. Mazalić 1956: 267.

2.15. Код села Горњи и Доњи Хумци на Мајевици има Марин град. Прича се да је почела да га зида нека Мара, Марија Терезија, и да је град тада имао више хиљада становника. Bojanovski 1974.

2.16. Прича се да је у Стржњу била краљица Марија Терезија, и да је онда била тако топла клима, да уопште није било зиме. И када је она била у Стржњу, који је тада био главни град, пао је снијег на Маловану, слуге су јој рекле. Она је послала неколико слугу да јој донесу „оно бијело што има на Маловану“. Они јој донијели, а она позвала неке своје мудраце да јој кажу шта је то. Они јој казали: „За вас није добро! Војске ће доћи овако бијелих чалми и потиснуће владавину!“ И онда се она одмах припремала за бјекство. Наопако потковала коња и побјегла, а када је војска дошла у дворац мислила је да 
је неко дошо у дворац, па су све претресли, али је она већ далеко отишла. У Араповини је краљица имала стоку и мљековод, дуг два километра, до у Стржањ. ФАЗМ, XVI-Г, 6227. Забиљежила у Шуици код Дувна РФ 1957.

2.17. Старе градове у сјеверној Босни (Градачац, Сребрник, Добор и Соко код Грачанице) градиле су кћери Марије Терезије. ФАЗМ, Х-Г 5088, забиљежила РФ.

\section{3. Космогонијски аспекти женске креативности: од ограде до града}

Сугестивну и инспиративну основу за промишљање о значењским структурама народних предања о подизању града пронашли смо у раду Рајке Полић „Све се врти око врта (копље од оруђа до оружја; град од врта до утврде“" (Polić 2008). Кратак преглед у фоми неколико цитата у функцији је успостављања семантичког оквира за тумачење одабраних текстова народне књижевности у којима доминира женско градитељско начело:

Doprinos žena u razvoju kulture direktno je povezan sa samim pojmom colere, koji se izvodi iz aktivnosti oko uzgoja biljaka i obrađivanja zemlje, u čemu su osnovnu ulogu u početku imale žene. Kao skupljačice, žene su kopale i otkopavale biljke kopljem i naučile kako ih mogu same saditi. Time je započela kultura vrtova koja je u svijest ljudi trajno usadila pojam raja, mjesta na zemlji gdje je čovjek sretan, ali i dovela do spoznaje o načinu začeća djeteta (...). S patrijarhatom, koji se gradi na očinskoj ulozi, nastupa zaborav doprinosa žena u stvaranju kulture. Koplje, oruđe u rukama žene, postalo je i ostalo isključivo oružje u rukama muškarca. Osim što je potisnuta iz povijesti, žena je optužena za gubitak raja na zemlji, a s vremenom proglašena i za opasnost koja može ugroziti i neki budući raj. (Polić 2008: 177) 
Kulturu vrta obilježava uzgajanje biljaka na prostoru zaštićenom ogradom (o-grad-om). (...) Prvobitni je slavenski naziv za vrt bio grad (sveslavenski i praslavenski gordz, starocrkvenoslavenski gradz), a kasnije gràdina, što znači »ograđeno mjesto«. »To se značenje objašnjava sa stcslav. grads 'ograđeno mjesto, vrtal, $\kappa \eta \pi о \varsigma$ '. Značenje grads ' $v r t$ ' očuvano je do danas u augmentativnoj izvedenici na -ina: gràdina. U tom značenju ne živi danas više u hrv.-srp. jeziku nego u bug. gradina,... Homonim gràdina f'ruševina staroga grada' potiskuje gradinu u značenju 'vrt' u zaborav.« (Skok, 1971., 603) U rumunjskom jeziku gard je »ograda od pruća, plot« (Skok, 1971., 603). U francuskom jardin (vrt) dolazi od starofrancuskog gart, jart, odnosno franačkog gard, što znači "polje okruženo plotom " (Hachette, 1989., 882). U engleskom jeziku vrt je garden, a u njemačkom Garten. (Polić 2008: 181)

Za vrt je karakterističan određeni red gredica, lijeha, drvoreda i nasada biljaka koji se oštro odvaja od kaosa izvan ograde, gdje biljke rastu nepredvidivo. Ujedno taj red, kao izraz namjere i cilja vrtlarice, svjedoči o njezinoj moći da snagu i energiju Sunca, životnost tla i vode podredi svojoj volji. (...) Od grada (vrta) ostala je samo ograda ispunjena novim sadržajem i idealizirano sjećanje na doba bezbrižnog života u raju. $\mathrm{Na}$ višku proizvoda zemljoradnika izdigao se novi grad kao ograđeno mjesto življenja, ali ne više bezbrižnog života među biljkama, nego gusto naseljeno mjesto među bedemima za zaštitu od neprijatelja, koje simbolično u obliku krune pripada vladaru. (...) Muški je grad civilizacijski nastavak ženskog grada, samo što su u njemu umjesto gredica poredane ulice i trgovi. Grad je to uređeniji što njegovi vrtovi pružaju stanovnicima više ljepote. Grad je Red nasuprot Kaosu, bilo kao vrt ili utvrda. (Polić 2008: 182, 186)

Као могућу синтезу изнесених ставова, стилизовану у низу усменопоетских метафора, наводимо стихо- 
ве лирске народне пјесме коју је 1866. године учитељ Максим Крстић послао часопису „Вила“:

Маглица се пољем повијала,

То не била танана маглица,

Већ то била Ђурђева Јерина.

Она ми се са ђевери кара:

„О, ђевери, моји неђевери,

Не газ'те ми с коњма винограде;

Ако и јест Ђурађ погинуо,

Остало је девет Ђурђевића,

Оградиће они винограде

Златним кољем и сребрним прућем. (Матицки 1985:104)

\section{4. Митски синопсис у фолклорној визури}

4.1. Црна краљица се појављује у предањима забиљеженим углавном на сјеверозападу српског етничког простора, у сижејним моделима које граде разноврсни, махом митолошки мотиви. Њени поданици су различито именовани, а особине које им се приписују указују на то да је ријеч о представама које се везују за најстарије слојеве становништва у динарским крајевима: „Старом, некадашњем народу приписују се дивовске, натприродне ососбине; за све групе старог становништва наводе се исти или слични мотиви, свима се приписују слични, али и различити материјални остаци у локалном пејзажу: Грцима, Каурима, Маџарима, Угрима, Луторанима и Џидовима“ (Палавестра 2003: 110). Вријеме њене владавине је митско космогонијско вријеме, када се демијуршким захватима обликују клима, пејзаж и човјек: камен је био мекан, у Босни је било 
море, имали су по три жетве годишње, снијег никад није падао, и планине су биле обрасле и засијане, народ је био богат, многобројан и дуговјечан, људи били веома високи и снажни, стада су била непрегледна, а млијеко је текло низ планине (в. Палавестра 2003: 133137). Старом народу дивова приписују се грандиозни грађевински подухвати: „Кључки град се прије звао Пролом, јер је Црна краљица отворила литицу да истече језеро“; „Диви су прокопали неђе и одвратили из Босне море“ (Палавестра 2003: 133-134). О хтонском карактеру Црне краљице (Чајкановић 1994: 72) закључује се на нивоу именовања, атрибуција и специфичних детаља (имала је златну квочку, златне пилиће, златан ткалачки разбој). Предања о народу дивова и њиховој краљици говоре и о нестајању, односно напуштању Босне као посљедици спознаје да је златно доба (aurea aetas) неповратно нестало: „Кад једно јутро из двора изиђе, видје у стопи волујској лед, и види да нема мјеста, и крене“ (Палавестра 2003: 134). Судећи према логици митског мишљења и семантици просторних релација, напуштање „свог“ простора и прелазак у „туђи“ повлачи демонизацију старог народа који је у предањима јасно означен као „Други“ и другачији (горостасни, дуговјечни, тамнопути, агресивни, ружни), а сходно томе, и њихове владарке. Напуштање Босне под драматичним околностима средишњи је мотив предања о краљици Катарини Косачи $^{3}$, и тачка из које се отвара простор за преплитање и наслојавање мотива (о бијегу из града под опсадом, издаји, закопаном благу, траговима у камену, и сл.), при чему ће се улога владарке и заповједнице града додјељивати изоморфним ликовима Црне краљице,

3 У којима се „златно доба“ окончава турским освајањем Босне. 
Катарине Косаче, Јерине Бранковић и Марије Терезије.

4.2. Еротске конотације метафора и сижејних модела које најављује формула „кулу гради“ (или „град градио/ла“) и „башту сади“ већ су потврђене анализом разноврсних усменопоетских текстова (Пандуревић 2016:19-20), при чему је указано да фолклорна грађа забиљежена на српском језику посредством ових мотива не исказује јасно позициониране родне улоге 5 . Напротив, и „градња“ и „садња“ препуштене су мушким, као и женским ликовима, матријархалним и патријархалним концепцијама и преосмишљавањима ${ }^{6}$ :

Синоћ Марка оженила мајка, Јутрос му се разбољела љуба. Заискала грожђа ђунђибера, Из царева рана винограда, Што је царе рано посадио, И сребрном притком приколио, И злаћаном жицом привезао. (Матицки 1985: 103-104)

Пјесма Град градило младо момче/ међу очи $y$ дјевојке (Вук V, 574) има јасно исказане еротске конотације, док пјесма Башчу сади Ђулић барјактаре (Босанска вила 1892/20-21:325) у амбијенту родне и плодне башче развија метафору „ловца и ловине“ својствену љубавним лирским пјесмама. Утисак да

4 О механизму мишљења који омогућава алтернације види у (Пандуревић 2008: 95)

5 Два се града напоредо граде/једно Јајие а друго Језеро./Јајие гради Јајчанине Иво/а Језеро Језеркиюа Маре (VM I, 144)

6 У простору оваквог осмишљавања требало би тражити узроке спора између виле и Мрњавчевића поводом зидања Скадра на Бојани. 
су башча и градина повлаштени простори женског испољавања, остаће пољуљан пред налетом разузданог и ласцивног бећарца, у коме нема мјеста за недоречено и наслућено, у коме еротским метафорама није остављен простор да буду и другачије протумачене: Ајде, мала, пусти своме роћку/испод пупка да посади воћку.

4.3. У митолошким пјесмама на тему „вила зида град“, гдје се исходишта метафоре градозидања доводе у везу са обредима еротског и брачног везивања, јасно се уочава тензија између мушког и женског начела и укрштање двије различите хијерархије: митске и космогонијске, у којој је доминантна градитељица и родитељица, и патријархалне - витешке и ратничке - у којој је доминантан мушкарац (в. Пешикан Љуштановић 1995: 201-210):

Град градила бјела вила Ни на небу, ни на земљу, Но на грану од облака; На град гради троје врата: Једна врата сва од злата, Друга врата од бисера, Трећа врата од шкерлета. Што су врата суха злата, На њих вила сина жени; Што су врата од бисера, На њих вила кћер удаје, Што су врата од шкерлета, На њих вила сама сједи,

Сама сједи погледује,

Ђе се муња с громом игра, Мила сестра су два брата, А невјеста с два ђевера; Муња грома надиграла, 
Мила сестра оба брата,

А невјеста два ђевера. (Вук I, 226)

Вила господари чудесним градовима који се указују ни на небу ни на земљи, али и онима саграђеним "од силне коњске кости и од јуначке“ (Pavlović 1986, 102-114; Пешикан-Љуштановић 1995, 201-210; Лома 2002, 146; Самарџија 2006, 41-42), потврђујући свој комплексни митолошки профил у садејству смрти и рађања које својим присуством и дјелатношћу иницира, односно жудње и страха које изазива.

У усменој традицији Јеринин лик поприма вилинска обиљежја кроз поређења, именовања, епитете и метафоре у лирским и епско-лирским пјесмама (в. Пандуревић 2016:24), а на специфичан начин их испољава и у епским сижеима у којима фигурира као невјерна жена, сурова владарка, објесна супруга, немилосрдна мајка. У предањима се говори и о томе како је подизала градове „на кулук“, јела само језик (или само срце) рогате марве, и захтијевала огроман труд и одрицања од својих поданика откривајући тако потенцијалне елементе за профил хтонске богиње којој су приношене жртве и подизани храмови. У процесу усменопоетског уобличавања, византијска принцеза Ирина Кантакузина, односно српска деспотица Јерина Бранковић, иако аутентична историјска личност, заузела је упражњено мјесто из регистра типских јунака, а догађаји у вези с њом, без обзира на евентуалну историјску утемељеност, добили су симболичка значења која се артикулишу у систему митских слика и симбола. Из аспекта матријархалног принципа, њена (и не само њена) изразито наглашена сексуалност и похотљивост (без икаквог утемељења у историографској реконструкцији) исходиште имају у атрибуцијама велике Богиње Мајке: 
„Она (Јерина, Ј.П) је имала своју војску...Кад би јој затребај мушко, она узми по ноћи војника и ноћи с њиме, а ујутро га убиј да не казује. (...)

Прича се да је била Црна краљица, Терези Марија. Зовне војника, „оправи“ с њим и убије га послије“ (Палавестра 2003: 304-305)

4.3. У јуначкој епици Јерина учествује у државним пословима, командује војском, доноси одлуке, подиже утврђење, односно, осваја простор јавног дјеловања који је у патријархалном концепту културе резервисан за мушкарца (в. Пандуревић 2011: 21-31). Овај преступ платиће „проклетством“ које је јасна ознака за њено неприпадање заједници. Патријархална укроћеност женског бића у првом реду се односи на контролисану сексуалност и бескомпромисно наметање родних улога на релацији јавно-приватно. Нарушавање хијерархијске структуре у којој доминира мушкарац, оштро је санкционисано, нарочито у јуначким, породичним и вјерским пјесмама. Тако је женска самосвијест о сексуалности и моћи прекодирана у обиљежје идеолошки неприхватљивог и јавно жигосаног. У предањима међутим, нема осуде, омаловажавања и унижавања, упркос очигледно негативном интензивирању ликова, њихових навика и склоности, темперамента и карактера. Измјештањем у давно прошло вријеме успоставља се дистанца спрам Другог ${ }^{7}$, јер преузимање владарског трона, заповједничке иницијативе и јавно, неспутано испољавање еротске жудње пресудно је утицало на ак-

7 Наглашавање дистанце и активирање сематичке опозиције својтуђи уочава се на различитим нивоима. Уп. Исказ Хакије Вилића из Жепе: „Не знам каква је држава њу ишћерала, само се прича да је потковала коње наопако, и, кажу, побјегла. Наше комшије Срби зову је Проклета Јерина“ (ФАЗМ XXV-Г, 13860, 1961) 
тивирање представа о демонским женским бићима, о којима се не суди на основу патријархалног концепта родних улога. Осим тога, жанровска стратегија предања не почива на морализовању, него на посредовању искуства, личног и колективног, заснованог на вјеровању и културном памћењу.

\section{Умјесто закључка ${ }^{8}$}

У закључку се намеће утисак да су, упркос историјским, псеудоисторијским и културноисторијским реминисценцијама, народна предања о подизању градова и утврђења, њиховом разарању и напуштању, веома блиска митолошким и демонолошким предањима. Осовину овог семантичког „обрата“ представљају ликови жена, владарки и градитељица, обликовани у процесу амалгамског прожимања митског и историјског, и њиховог увирања у сложене и динамичне токове културног памћења.

Зидање смедеревске тврђаве у епским пјесмама и културно-историјским предањима представљено је као низ огрешења о светиње патријархалног морала, а њен пад запамћен је као дефинитиван слом Србије, немоћне да се одупре турској најезди. Сагледана кроз призму „пошљедњег времена“, историјска реалност смедеревског градозиданија постала је тема достојна јуначке епике. Али, подизање града, иако сакрални чин (Елијаде 1998) који у митовима и древним еповима потврђује моћ и славу јунака, у српској усменој епици само је изузетно функционисао као централни мотив. Преовладава утисак да је подизање задужбина, цркви и манасти-

8 Закључак се готово у цјелини преузима из (Пандуревић 2011a : 398) 
ра, далеко више присутно као епска тема. Разлози за то свакако су и у самој природи усмене комуникације која се не ослања само на подразумијевана знања колектива, него и на његове подразумијеване емоције. Једна од посљедица турског освајања Балкана је карактеристично груписање становништва које се у Босни и Херцеговини задржало вијековима. Због сталне опасности од турског зулума хришћанско становништво је напуштало земљиште у равницама и дуж друмова, и постепено се повлачило у више, недоступне крајеве, враћајући се примитивнијим формама живота, док су муслимани насељавали долине ријека и, нарочито, градове. Ове миграције становништва утицале су и на промјену перспективе у епском сагледавању односа своје-туђе, тако да градови и утврђења постају носиоци негативне семантике (Детелић 1992).

\section{Скраћенице и извори:}

Bejtić 1958 -Bejtić, A. Bosanski namjesnik Mehmed-paša Kukavica i njegove zadužbvine u Bosni. POF VI-VII, Sarajevo 1958.

Bojanovski 1974 - Bojinovski, I. „Dolabelin sistem cesta u rimskoj provinciji Dalmaciji“. ANUBiH, Djela 47, Centar za balkanološka istraživanja 2, Sarajevo 1974.

БВ - Босанска вила. Лист за забаву, поуку и кюижевност. Сарајево (1885-1914)

VM I - Milošević, Vlado. Bosanske narodne pjesme I. Banja Luka: Muzej Bosanske krajine, 1954.

ВП - Влајко Палавестра

Вук I - Караџић, В. С. Сриске народне пјесме I, Сабрана дјела B. С. Карачића. књ. IV, В. Недић (прир.). Београд: Просвета, 1975.

Вук В -Караџић, В. С. Српске народне пјесме. Книга пета у којој су различне женске пјесме. Љубомир Стојановић (прир.). Београд: Државно издање 1898. 
Грђић-Бјелокосић 1892 - Грђић Бјелокосић, Л. „Кози-град, Звони-град и Градина у котару Фојничком“. Гласник Земаљьског музеја. IV. Sarajevo 1892.

Матицки 1985 -Матицки, М. Народне песме у Вили. Нови Сад-Београд: Матица српска - Институт за књижевност и уметност, 1985.

Mazalić 1956 -Mazalić, Đ. „Zvonik (Zvornik) stari grad na Drini“ . GZM, n.s. Istorija i etnografija XI, Sarajevo 1956.

Palavestra 1964 -Palavestra, V. „Narodne pripovijetke i predanja“. Etnološko folkloristička istraživanja u Žepi, GZM (Etnologija), n.s. XIX, Sarajevo 1964.

Палавестра 2003 - Палавестра, В. Хисторијска усмена предаға из Босне и Херцеговине. Мирослав Нишкановић (прир.). Београд: Српски генеалошки центар, 2003.

РФ - Радмила Филиповић Фабијанић

ФАЗМ - Фолклорни архив Земаљског музеја у Сарајеву Филиповић 1924 -Филиповић, М. С. „Дубровник у Босни“. ГЗМ ХХХVI (1924): 101-106

\section{Литература:}

Bošković Stulli 1975 - Bošković Stulli, M. Usmena književnost kao umjetnost riječi. Zagreb, 1975.

Детелић 1992 - Детелић, М. Митски простор и епика. Београд: САНУ, 1992.

Елијаде 1998 - Елијаде, М. Свето и профано. Београд: Доситеј, 1998.

Лома 2002 - Лома, А. Пракосово. Словенски и индоевропски корени српске епике, Балканолошки институт САНУ, посебна издања 78. Београд: Центар за научна истраживања САНУ и Универзитета у Крагујевцу, 2002.

Pavlović 1986 - Pavlović, M. Obredno i govorno delo. Beograd: Prosveta, 1986.

Пандуревић 2008 - Пандуревић, J. „Жене-владарке и културноисторијска предања“. Научни састанак слависта у Вукове дане 37/2 (2008): 91-101.

Пандуревић 2011 - Пандуревић, Ј. „О епским ратницама и хајдучицама, или о игри идебнтитета у српској народној 
епици“. Д. Бошковић (ур.). Жене: род, идентитет, книжевност. Крагујевац: ФИЛУМ, 2011. 21-31.

Пандуревић 2011а - Пандуревић, J. „О чудесним, подземним и летећим црквама српске усмене традиције“. М. Детелић и С. Самарџија (ур.). Жива реч. Београд: Балканолошки институт САНУ и Филолошки факултет Универзитета у Београду, 2011. 397-416.

Пандуревић 2016 - Пандуревић, J. „Фолклорни еротикон између обредне и поетске метафоре“. Книжевна истоpuja XLVIII (2016), 159: 9-36.

Пешикан Љуштановић 1995 - Пешикан Љуштановић, Љ. „Сјајна кошуља - између митолошке и породичне песме“. Зборник Матице српске за књижевност и језик, књ. XLIII, 2-3 (1995): 201-210.

Пешикан Љуштановић 2007 - Пешикан Љуштановић, Љ.,Свете и проклете - жене из породице Бранковића у историји и усменој традицији“. Станаја село запали. Нови Сад: Дневник 2007. 99-133.

Polić 2008 - Polić, R. „Sve se vrti oko vrta. Koplje od oruđa do oružja, grad od vrta do utvrde“. Filozofska istraživanja 109, god. 28 (2008), sv. 1: 177-192.

Röhrich 1966 -Röhrich, L. Sage. Stuttgart, 1966.

Самарџија 2006 - Самарџија, С. „Слојеви једне метафоре (између календарске године и патријархалне задруге)“. Годишњак Катедре за српску књижевност са јужнословенским къижевностима, Год. II. Београд: Филолошки факултет, 2006. 39-75.

Чајкановић 1994 - Чајкановић, В. „О врховном богу у старој српској религији“. Београд: СКЗ, БИГЗ, Просвета, Партенон M.A.M, 1994. 
Jelenka Pandurević

\section{FOLK TRADITION ABOUT CITIES: ORAL HISTORY OR CULTURAL MEMORY}

In the approach to national traditions recorded in Bosnia and Herzegovina, the phenomena of oral tradition and cultural memory are presented through a creative oral-poetic dialogue between fiction, history and myth. Fortresses, settlements and buildings are the subject of stories about rulers and owners, construction and endowment, demolition and conquest, as well as beliefs related to the remains of ruins. As a specific amalgam of mythical thinking and historical memory, this paper highlights the complexities of tradition about female builders, and provides an overview of current studies and current interpretations

Key words: folk traditions, fortresses and cities, female builders and rulers, oral history, cultural memory. 